\title{
Analisis Pembasahan Lahan Gambut akibat Pembangunan Sekat Kanal (Studi Kasus: Desa Lukun, Kabupaten Kepulauan Meranti)
}

\author{
Hafiz Alfarisyi ${ }^{1}$, Sigit Sutikno ${ }^{2}$, Rinaldi ${ }^{3}$ \\ 1,2,3 Program Studi S1 Teknik Sipil, Fakultas Teknik, Universitas Riau \\ Kampus Bina Widya Jl. HR. Soebrantas Km 12,5 Pekanbaru, Kode 28293 \\ Email: hafiz.alfarisyi@student.unri.ac.id, sigit.sutikno@lecturer.unri.ac.id, ri.naldi@eng.unri.ac.id
}

\begin{abstract}
ABSTRAK
Restorasi gambut sangat diperlukan untuk merehabilitasi ekosistem gambut. Badan Restorasi Gambut (BRG) telah menerapkan upaya restorasi gambut salah satunya melalui kegiatan rewetting (pembasahan lahan gambut kembali dengan pembuatan sekat kanal) di dalam wilayah Kesatuan Hidrologi Gambut (KHG). Desa Lukun memiliki lahan gambut yang terbakar dan terdegradasi cukup luas. Dengan adanya pembasahan kembali gambut, diharapkan gambut yang terganggu hidrologinya akan mengalami perbaikan dan gambut akan tetap dalam kondisi basah sehingga laju degradasi dan potensi kebakaran gambut dapat dicegah. Oleh karena itu dilakukan analisis pembasahan lahan gambut akibat pembangunan sekat kanal dengan menggunakan water level logger yang dipasang pada beberapa sumur pantau yang ada di sekitar kanal. Hasil yang diperoleh dari water level logger berupa tekanan hidrostatis dan tekanan atmosfer yang kemudian diolah menjadi grafik fluktuasi muka air tanah. Pada penelitian ini menunjukkan hasil bahwa sekat kanal memiliki dampak terhadap fluktuasi muka air tanah sebagai upaya pembasahan lahan gambut dan radius pembasahan yang dihasilkan akibat penyekatan kanal mencapai kurang dari 100 meter. Selain sekat kanal, kenaikan muka air tanah juga dipengaruhi oleh curah hujan.
\end{abstract}

Kata Kunci: water level logger, muka air tanah, sekat kanal, sumur pantau, pembasahan lahan gambut.

\begin{abstract}
Peat restoration measures are needed to rehabilitate peat ecosystems. The Peat Restoration Agency (BRG) has implemented peat restoration efforts one of them through rewetting activities within the territory of the Peat Hydrological Unity $(K H G)$. The village of Lukun has burnt and degraded peatlands. With the rewetting of the peat, it is expected that the hydrologically disturbed peat will be improved and the peat will remain in wet conditions so that the degradation rate and potential of peat fires can be prevented. Therefore, the analysis of the peatlands wetting area due to the construction of canal blocking using the water level logger was set up in several monitoring wells around the canal bloking area. The results of water level logger give a reading in the form of hydrostatic pressure and atmospheric pressure then processed into graphs of groundwater fluctuations. This research showed the results that canal blocking has an impact on ground water level fluctuations as an effort to wet peatlands and the wetting radius that results from canal blocking is less than 100 meters. Besides the canal blocking, the increase in groundwater level is also influenced by rainfall.
\end{abstract}

Keywords: water level logger, groundwater level, canal blocking, monitoring wells, peatlands rewetting.

\section{PENDAHULUAN}

Indonesia memiliki luas lahan gambut berkisar antara 21 juta hektar atau 10 persen dari luas daratan Indonesia. Lahan gambut tersebut tersebar di pulaupulau besar yaitu Papua ( 8 juta Ha), Sumatera $(7,2$ juta Ha) dan Kalimantan (5,8 juta Ha) (Rais, 2011).

Sebagian besar lahan gambut di Indonesia dimanfaatkan sebagai lahan perkebunan. Kegiatan pembukaan lahan yang diikuti dengan pembangunan saluran-saluran drainase (kanal buatan) telah menyebabkan penyusutan volume gambut. Pembangunan jaringan kanal drainase yang tidak terkontrol di ekosistem gambut akan meningkatkan laju aliran air (overdrain) dan menurunkan daya simpan air (retensi) pada ekosistem gambut. Hal ini akan menyebabkan muka air gambut turun drastis dan gambut akan mengalami kekeringan sehingga bisa menyebabkan kebakaran lahan. Dampak lain dari penurunan muka air gambut adalah terjadinya penurunan permukaan tanah (land subsidence) akibat adanya oksidasi, konsolidasi dan pemadatan gambut (Hooijer, 2012). Namun hal itu dapat diantisipasi dengan pembangunan sistem drainase yang baik dan melakukan program pembasahan kembali gambut. Salah satu teknik pembasahan gambut yang bisa diterapkan yaitu dengan membuat sekat kanal 
(Canal Blocking) untuk menaikkan muka air tanah (Dohong, et al., 2017).

Prinsip kerja sekat kanal adalah menahan dan menampung air selama mungkin di wilayah Kesatuan Hidrologis Gambut (KHG). Teknik pembasahan gambut dengan sekat kanal dapat dilaksanakan di kawasan dengan fungsi budidaya maupun kawasan konservasi/lindung, dengan perbedaannya terletak pada perangkat pengatur muka air berupa peluap atau pelimpah air (Spillway). Dengan begitu sistem kanal ini akan membuang kelebihan air ketika musim hujan dan menahan air saat musim kemarau. Sehingga air tanah akan terjaga, gambut akan kembali basah dan tidak mudah terjadi kebakaran ((Dohong, et al., 2017).

Tujuan dari penelitian ini adalah untuk melakukan analisis dampak pembangunan sekat kanal terhadap fluktuasi muka air tanah sebagai upaya restorasi gambut yaitu pembasahan lahan (rewetting) di Desa Lukun.

\section{METODE PENELITIAN}

\section{Lokasi Penelitian}

Lokasi penelitian berada di Desa Lukun, Kecamatan Tebing Tinggi Timur, Kabupaten Kepulauan Meranti, Provinsi Riau.

\section{Pipa PVC (polyvinyl chloride) Sebagai Sumur Pantau}

Sumur pantau digunakan sebagai alat pengendalian penggunaan air tanah yang berfungsi untuk memantau dan mengecek fluktuasi muka air tanah di lahan sekitar kanal yang disekat. Sumur pantau pada penelitian ini terbuat dari pipa PVC yang memiliki diameter 2 inci, panjang $200 \mathrm{~cm}$ dan tebal $3 \mathrm{~mm}$. Pada bagian bawah pipa PVC terdapat lubang dengan jarak masing-masing $1,5 \mathrm{~cm}$. Lubang tersebut berfungsi agar air tanah gambut dapat merembes masuk kedalam pipa. Sumur pantau yang digunakan dapat dilihat pada Gambar 1 berikut.

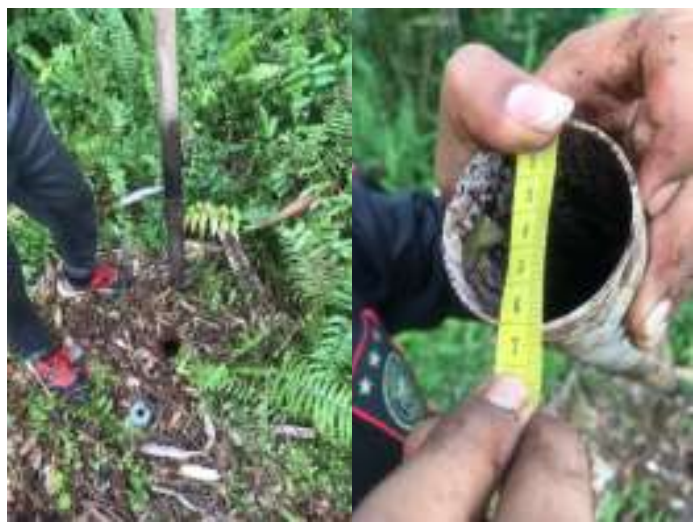

Gambar 1. Sumur Pantau Yang Digunakan Pada Lokasi Penelitian
Jumlah sumur pantau ditentukan berdasarkan kompleksitas hidrologi dan ukuran wilayah pemantauan (Bonnett dkk., 2009). Terdapat 15 sumur pantau dan 3 transek yang ada di lokasi penelitian dengan 1 transeknya terdiri dari 5 buah sumur pantau dengan jarak $1 \mathrm{~m}, 51 \mathrm{~m}, 101 \mathrm{~m}, 201 \mathrm{~m}$ dan $301 \mathrm{~m}$ dari sisi kanal. Sketsa letak sumur pantau dan sekat kanal dapat dilihat pada Gambar 2 berikut.

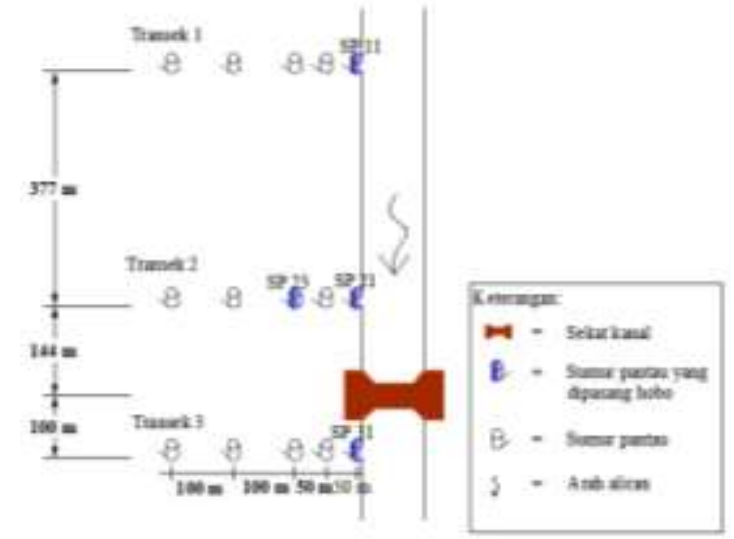

Gambar 2. Sketsa Letak Sumur Pantau dan Sekat Kanal

\section{Water Level Logger}

Pengukuran tinggi muka air tanah dapat diukur secara manual atau menggunakan alat otomatis. Pengukuran tinggi muka air diukur dengan menggunakan alat ukur otomatis berupa water level logger yang bermerk HOBO. Water level logger tersebut dapat mengukur level air, tekanan mutlak, tekanan barometrik, suhu dan ketinggian air dengan akurasi tinggi. Water level mudah digunakan dan dilengkapi dengan software untuk memantau pengukuran water level secara langsung melalui grafik di aplikasi alatnya. Data pengukuran real time yang terekam pada water level dapat diambil melalui USB (Taharica Group, 2018).

Water level logger dipasang didalam pipa sumur pantau. Sebelum dimasukkan kedalam sumur pantau, water level logger diikat terlebih dahulu dengan menggunakan tali, hal ini dilakukan untuk mempermudah dalam proses pengambilan water level logger dari dalam sumur pantau. Terdapat 5 water level logger merk HOBO yang digunakan, 4 diantaranya diletakkan di dalam sumur pantau dan 1 water level logger diletakkan di luar sumur pantau. water level logger di lokasi penelitian dapat dilihat pada Gambar 3. 


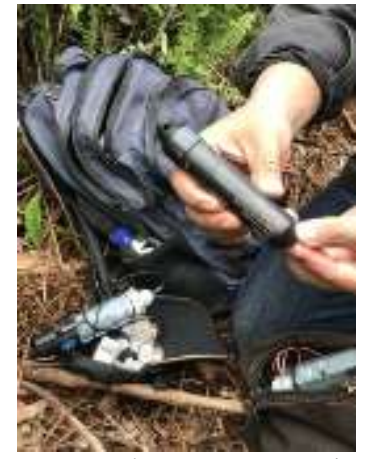

Gambar 3. Water Level Logger yang Digunakan Pada Lokasi Penelitian

Data yang didapat dari alat pengukur water level logger berupa data tekanan dan tekanan udara, kemudian data tersebut diolah menjadi data elevasi Muka Air Tanah (MAT).

\section{Analisis Data}

Data yang diperoleh dari Water Level Logger akan di analisis menjadi data elevasi Muka Air Tanah (MAT) sebagai berikut.

A. Meganalisis data Water Level Logger menjadi data Tinggi Muka Air (MAT) karena data dari Water Level Logger merupakan data tekanan. Adapun hal-hal yang harus dilakukan adalah sebagai berikut.

1) Pada penelitian ini Water Level Logger dipasang di dalam sumur pantau untuk mendapatkan data tekanan (pressure) dan di luar sumur pantau untuk merekam data tekanan udara. Data Water Level Logger yang sudah direkam kemudian di download dan diplot menjadi grafik dengan menggunakan aplikasi Water Logger ware yang kemudian di Export ke Microsoft Excel. Data rekaman Water Level Logger dapat dilihat pada Tabel 1.

Tabel 1. Data Rekaman Pada Transek 2 SP21 dan Tekanan Udara

\begin{tabular}{cccc}
\hline Detik & Waktu & $\begin{array}{c}\text { Tekanan } \\
\text { Hidrostatis } \\
(\text { Kpa) }\end{array}$ & $\begin{array}{c}\text { Tekanan } \\
\text { Udara } \\
\text { (Kpa) }\end{array}$ \\
\hline 1 & $11 / 7 / 201812: 00$ & 115,538 & 100,964 \\
2 & $11 / 7 / 201812: 00$ & 115,538 & 100,964 \\
3 & $11 / 7 / 201812: 00$ & 115,548 & 100,964 \\
4 & $11 / 7 / 201812: 00$ & 115,548 & 100,964 \\
5 & $11 / 7 / 201812: 00$ & 115,548 & 100,964 \\
6 & $11 / 7 / 201812: 00$ & 115,548 & 100,964 \\
7 & $11 / 7 / 201812: 00$ & 115,548 & 100,964 \\
8 & $11 / 7 / 201812: 00$ & 115,538 & 100,964 \\
9 & $11 / 7 / 201812: 00$ & 115,538 & 100,964 \\
10 & $11 / 7 / 201812: 00$ & 115,538 & 100,964 \\
\hline & & &
\end{tabular}

2) Untuk merubah data tekanan menjadi MAT maka dilakukan perhitungan sebagai berikut. Dimana $g=9.81 \mathrm{~m} / \mathrm{s} 2$ dan $\rho$ air $=1$ ton $/ \mathrm{m} 3$.

$$
\begin{aligned}
h & =\frac{P \text { hidrostatis }-P \text { udara }}{\rho \text { air } x g} \\
& =\frac{115,538-100,964}{1 \times 9.81} \\
& =1,487 \mathrm{~m}
\end{aligned}
$$

Keterangan:

$P \quad=$ Tekanan $\left(\mathrm{kN} / \mathrm{m}^{2}\right)$

$h \quad=$ Jarak ke permukaan zat cair (m)

$\rho$ air $=$ Massa jenis zat cair $\left(\mathrm{ton} / \mathrm{m}^{3}\right)$

$g \quad=$ Gravitasi $\left(\mathrm{m} / \mathrm{s}^{2}\right)$

3) MAT pada perhitungan diatas merupakan MAT diatas dari Water Level Logger. Maka untuk MAT total perlu ditambahkan sisa dari kedalaman Water Logger yang dimasukkan. Untuk mengetahui sisa kedalaman dari Water Logger dapat dihitung dengan cara sebagai berikut. Dengan kedalaman Water Logger yang dimasukkan adalah $175 \mathrm{~cm}$ dan kedalaman $\operatorname{sumur}(\mathrm{H})=2 \mathrm{~m}$.

Sisa kedalaman Water Level Logger $=200-175$

$$
=0,25 \mathrm{~m}
$$

4) Setelah MAT dari dasar sampai Water Level Logger diketahui maka MAT tadi ditambahkan dengan sisa kedalaman Water Level Logger. Dengan perhitungan sebagai berikut.

MAT normal = MAT diatas Water Logger + MAT di bawah Water Logger $=1,487+0,25$

$=1,737 \mathrm{~m}$

B. Setelah data dari Water Level Logger sudah menjadi data MAT, maka nilai kedalaman dapat diketahui dengan perhitungan sebagai berikut.

Kedalaman $=$ MAT normal - Tinggi sumur pantau di atas permukaan

$$
\begin{aligned}
& =1,737 \mathrm{~m}-0,17 \mathrm{~m} \\
& =1,567 \mathrm{~m}
\end{aligned}
$$

C. Setelah diperoleh data kedalaman, maka elevasi MAT bias didapat dengan perhitungan sebagai berikut.

Elevasi MAT = Elevasi Muka Tanah - Tinggi sumur pantau di atas permukaan - kedalaman $=10,45 \mathrm{~m}-0,17 \mathrm{~m}-1,567 \mathrm{~m}$ $=8,713 \mathrm{~m}$

Hasil perhitungan di atas dapat digambarkan pada Gambar 4 sebagai berikut. 


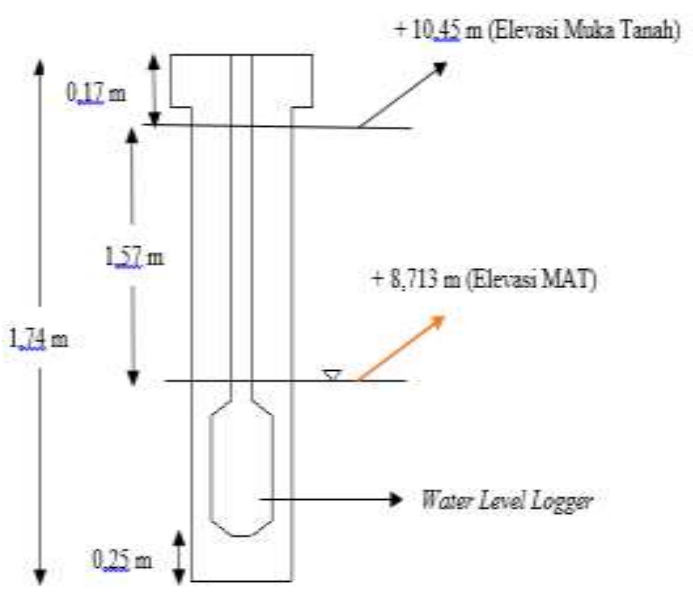

Gambar 4. Sketsa Hasil Perhitungan Elevasi Muka Air Tanah

D. Menganalisis data curah hujan yang diperoleh dari alat SESAME. Data yang direkam oleh alat SESAME real time dengan interval waktu pengukuran 10 menit sekali. Data curah hujan tersebut dianalisis menjadi data curah hujan harian. Data rekaman dari alat SESAME dapat dilihat pada table 2 berikut.

Tabel 2. Data Rekaman Curah Hujan Dari Alat SESAME

\begin{tabular}{ccccc}
\hline Tanggal & $\begin{array}{c}\text { Suhu } \\
(\text { celcius })\end{array}$ & $\begin{array}{c}\text { Soil } \\
(\%)\end{array}$ & $\begin{array}{c}\text { GWL } \\
(\mathrm{m})\end{array}$ & $\begin{array}{c}\text { Hujan } \\
(\mathrm{mm})\end{array}$ \\
\hline 18-10-03 00:00:00 & 23,2 & 35,131 & $-0,79$ & 0 \\
18-10-03 00:10:00 & 23,2 & 35,131 & $-0,79$ & 0 \\
18-10-03 00:20:00 & 23,2 & 35,131 & $-0,79$ & 0 \\
18-10-03 00:30:00 & 23,1 & 35,131 & $-0,79$ & 0 \\
18-10-03 00:40:00 & 23,1 & 35,131 & $-0,79$ & 0 \\
18-10-03 00:50:00 & 23,1 & 35,099 & $-0,79$ & 0 \\
18-10-03 01:00:00 & 23,1 & 35,066 & $-0,78$ & 0 \\
18-10-03 01:10:00 & 23,1 & 35,066 & $-0,78$ & 0 \\
18-10-03 01:20:00 & 23,1 & 35,033 & $-0,78$ & 0 \\
18-10-03 01:30:00 & 23,1 & 35,033 & $-0,78$ & 0 \\
\hline
\end{tabular}

E. Setelah data curah hujan dianalisis menjadi data curah hujan harian, maka data curah hujan tersebut dihubungkan dengan data kenaikan elevasi Muka Air Tanah (MAT) dalam bentuk grafik.

\section{Bagan Alir Penelitian}

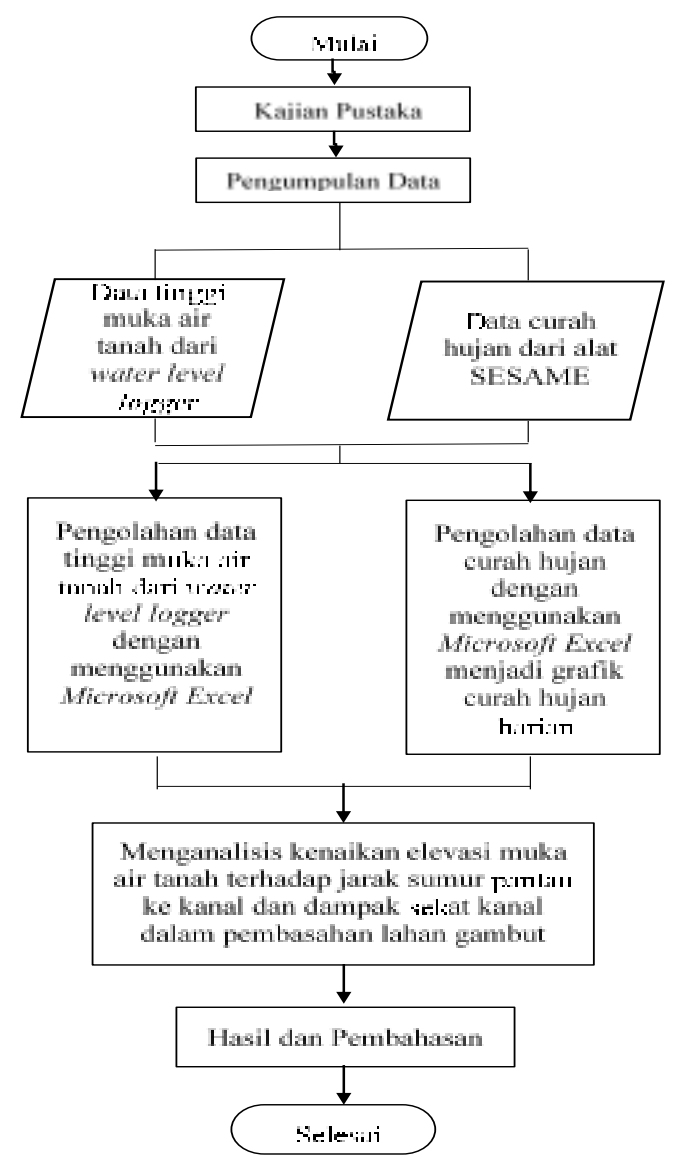

Gambar 5. Bagan Alir Penelitian

\section{HASIL DAN PEMBAHASAN}

\section{Hasil Survei Lapangan}

Hasil survei lapangan diperoleh beberapa data primer yang diambil pada saat penelitian. Daerah penelitian yaitu Desa Lukun, Kecamatan Tebing Tinggi Timur, Kabupaten Kepulauan Meranti. Dari 15 sumur pantau yang ada, hanya 4 sumur pantau yang diambil data muka air tanah dengan menggunakan instalasi water level logger yaitu sumur pantau SP11, SP21, SP23 dan SP31 yang berjarak $1 \mathrm{~m}$ dan $101 \mathrm{~m}$ dari kanal. Data yang diperoleh dari bulan Oktober 2018 hingga bulan November 2018.

\section{Data Curah Hujan}

Data curah hujan didapat dari alat pemantau muka air tanah real time (SESAME). Data curah hujan yang didapat yaitu berupa data curah hujan dengan interval waktu pengukuran 10 menit sekali. Data curah hujan tersebut dianalisis menjadi data curah hujan harian. Data curah hujan yang digunakan merupakan riwayat kejadian hujan dari tanggal 3 Oktober 2018 sampai tanggal 7 November 2018. Data curah hujan harian diolah menjadi grafik menggunakan microsoft excel dapat dilihat pada Gambar 6. 


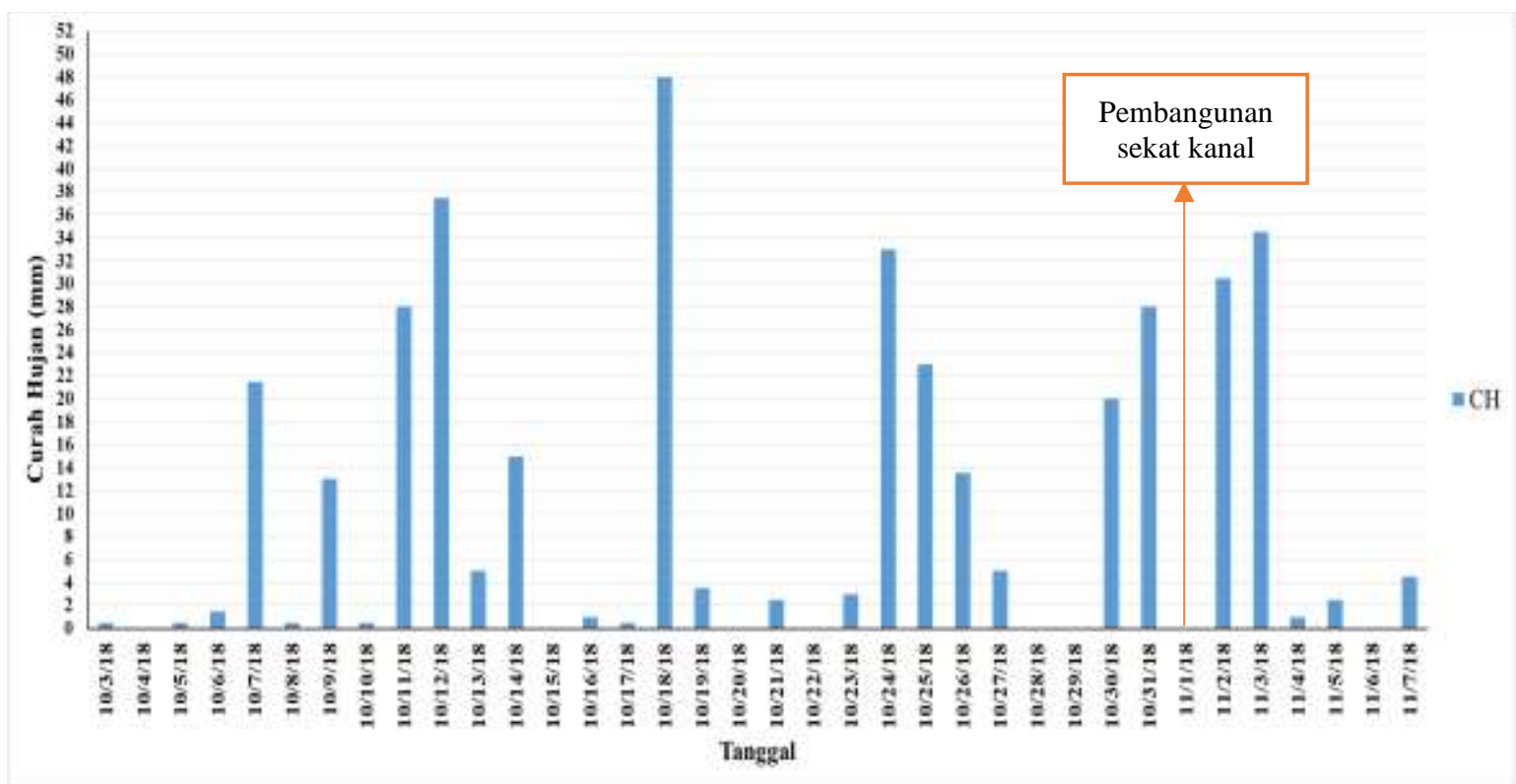

Gambar 6. Grafik Curah Hujan Harian pada Tanggal 3 Oktober 2018 sampai 7 November 2018

Data curah hujan diambil rentang tersebut karena untuk menyesuaikan terhadap data elevasi muka air tanah yang di dapat dari instalasi water level logger serta data curah hujan juga berguna untuk melihat pengaruh curah hujan terhadap elevasi muka air tanah sebelum pembangunan sekat kanal, setelah pembangunan sekat kanal untuk mengetahui keefektifan sekat kanal. Pembangunan sekat kanal dilakukan pada tanggal 1 November 2018, pada tanggal ini tidak terjadi hujan sehingga memudahkan kegiatan pembangunan sekat kanal di lapangan.

\section{Hasil Pengukuran}

Data pengukuran diperoleh dari instalasi Water Level Logger yang dipasang pada sumur pantau di sekitar kanal yang disekat dan di luar sumur pantau. Data yang diperoleh dari Water Level Logger berupa data tekanan hidrostatis dan tekanan udara atau atmosfer dari tanggal 3 Oktober 2018 sampai 7 November 2018 yang kemudian dianalisis menjadi data elevasi MAT.

\section{Analisis Fluktuasi Muka Air Tanah (MAT)}

Data yang diperoleh dari hasil pengukuran lapangan dengan menggunakan Water Level Logger yang kemudian dianalisis menjadi data elevasi MAT. Merubah data tekanan menjadi data Muka Air Tanah (MAT) diperlukan nilai g dan $\rho$ air. Dengan nilai percepatan gravitasi $\mathrm{g}=9,81 \mathrm{~m} / \mathrm{s}^{2}$ dan $\rho$ air $=$ $1000 \mathrm{~kg} / \mathrm{m}^{3}$ atau sama denga $1 \mathrm{ton} / \mathrm{m}^{3}$ (karena satuan Kpa sama dengan $\mathrm{kN} / \mathrm{m}^{2}$ maka nilai $\rho$ air yang digunakan 1 ton $/ \mathrm{m}^{3}$. Berikut merupakan salah satu contoh perhitungan elevasi MAT pada SP21, tanggal 21 Oktober 2018.

Diketahui:

Tekanan pada SP21

$$
=113,598 \mathrm{kN} / \mathrm{m}^{2}
$$

$\rho$ air $\mathrm{g}$

Tekanan udara

$$
=1 \mathrm{ton} / \mathrm{m}^{3}
$$$$
=9,81 \mathrm{~m} / \mathrm{s}^{3}
$$$$
=101,246 \mathrm{kN} / \mathrm{m}^{2}
$$

Tinggi sumur pantau di atas permukaan $=0,17 \mathrm{~m}$

Selisih kedalaman Water Level Logger dari sumur pantau $=0,25 \mathrm{~m}$

Elevasi Muka Tanah $\quad=10,45 \mathrm{~m}$

$$
\begin{aligned}
& \begin{array}{l}
\text { MAT dari Water Level Logger } \\
\text { Tekanan }- \text { Tekanan Udara }
\end{array} \\
& =\frac{1 \text { air x g }}{1 \times 9.81}
\end{aligned}
$$$$
=1,259 \mathrm{~m}
$$

$$
\begin{aligned}
\mathrm{H}= & \text { Kedalaman MAT dari atas Water Level Logger } \\
& - \text { Selisih kedalaman Water Level Logger dari } \\
& \text { sumur pantau } \\
= & 1,259 \mathrm{~m}+0,25 \mathrm{~m} \\
= & 1,509 \mathrm{~m}
\end{aligned}
$$

Kedalaman $=\mathrm{H}-$ Tinggi sumur pantau di atas permukaan

$$
\begin{aligned}
& =1,509 \mathrm{~m}-0,17 \mathrm{~m} \\
& =1,339 \mathrm{~m}
\end{aligned}
$$

Elevasi MAT = Elevasi Muka Tanah - Tinggi sumur pantau di atas permukaan kedalaman

$$
\begin{aligned}
& =10,45 \mathrm{~m}-0,17 \mathrm{~m}-1,339 \mathrm{~m} \\
& =8,942 \mathrm{~m}
\end{aligned}
$$

Analisis Fluktuasi Muka Air Tanah (MAT) Harian Pada Transek 1

Transek 1 terdiri dari sumur pantau SP11.

Elevasi MAT yang telah didapatkan akan 
dihubungkan dengan data curah hujan untuk melihat hubungan antara besarnya fluktuasi muka air tanah dengan sekat kanal serta curah hujan. Analisis ini dilakukan dengan menggunakan program microsoft excel. Hasil analisis kenaikan MAT pada Transek 1 dapat dilihat pada Gambar 7 berikut.

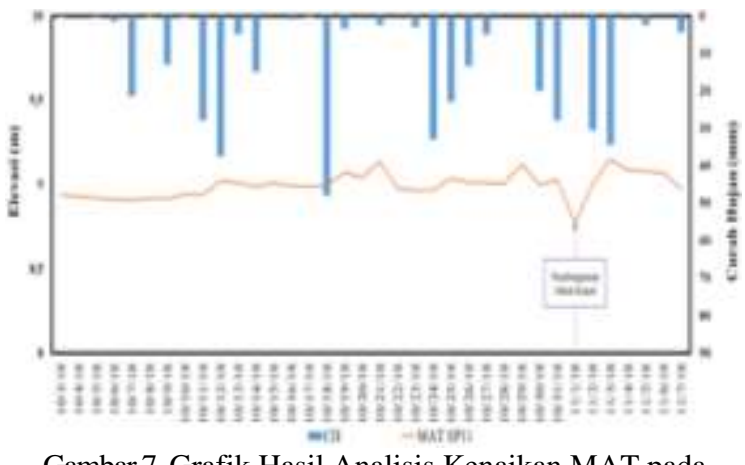

Gambar 7. Grafik Hasil Analisis Kenaikan MAT pada Transek 1

Gambar 7 di atas menunjukkan pengamatan elevasi MAT pada transek 1 yaitu pada sumur pantau SP11. Berdasarkan grafik tersebut menunjukkan bahwa Berdasarkan grafik tersebut menunjukkan bahwa sebelum adanya penyekatan kanal kenaikan MAT pada kedua sumur pantau dipengaruhi oleh curah hujan. Pada tanggal 1 November 2018, MAT pada SP11 turun drastis dikarenakan pada saat pembuatan sekat kanal dilakukan pembendungan untuk memudahkan pengerjaan pembuatan sekat kanal. Namun setelah adanya penyekatan kanal, kenaikan MAT pada SP11 terjadi pada tanggal 2 November 2018 sebesar 0,230 $\mathrm{m}$ dan pada tanggal 3 November sebesar 0,149 m. Kenaikan MAT dipengaruhi oleh penyekatan kanal dan jarak sumur pantau yang dekat dengan kanal, selain itu MAT juga dipengaruhi oleh curah hujan.

\section{Analisis Fluktuasi Muka Air Tanah (MAT) Harian Pada Transek 2}

Transek 2 terdiri dari sumur pantau SP21 dan SP23. Hasil analisis kenaikan MAT pada transek 2 dapat dilihat pada Gambar 8 berikut.

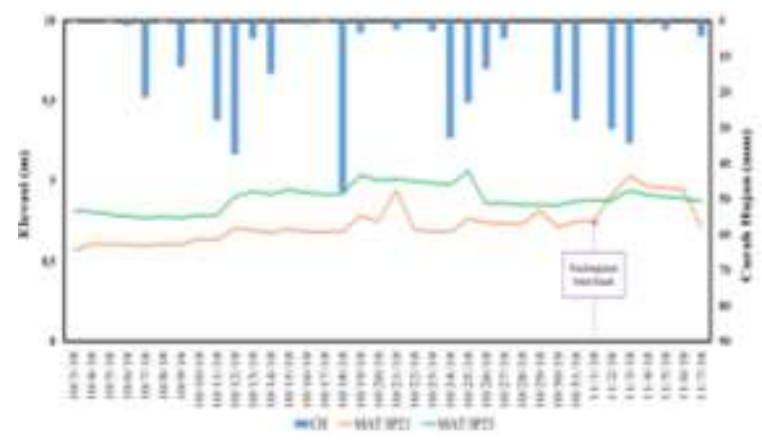

Gambar 8. Grafik Hasil Analisis Kenaikan MAT pada Transek 2
Gambar 8 di atas menunjukkan pengamatan elevasi MAT pada transek 2 yaitu pada sumur pantau SP21 dan SP23. Berdasarkan grafik tersebut menunjukkan bahwa pada awalnya sumur pantau SP21 tanggal 3 Oktober 2018 elevasi MAT hanya sebesar 8,566 m. Kemudian pada tanggal 12 Oktober 2018 elevasi MAT mengalami kenaikan menjadi 8,707 $\mathrm{m}$ yang dipengaruhi oleh curah hujan. Pada tanggal 19 Oktober 2018 elevasi MAT mengalami kenaikan menjadi 8,784 m juga disebabkan oleh curah hujan. Namun setelah adanya penyekatan kanal pada tanggal 1 November 2018, MAT mengalami kenaikan secara drastis pada tanggal 2 November 2018 yaitu sebesar 0,162 m sehingga elevasi MAT menjadi 8,911 m. Kemudian MAT mengalami kenaikan lagi pada tanggal 3 November 2018 sebesar 0,121 m sehingga elevasi MAT menjadi 9,032 m. Kenaikan MAT tersebut selain dipengaruhi oleh penyekatan kanal juga dipengaruhi oleh curah hujan serta dikarenakan jarak sumur pantau yang dekat dengan kanal. Sedangkan pada sumur pantau SP23, kenaikan MAT tidak terlalu dipengaruhi oleh sekat kanal hal ini disebabkan jarak sumur pantau yang jauh dari kanal yaitu $101 \mathrm{~m}$ dari kanal, sehingga radius pembasahan yang dihasilkan kurang dari $100 \mathrm{~m}$.

\section{Analisis Fluktuasi Muka Air Tanah (MAT) Harian Pada Transek 3}

Transek 3 terdiri dari sumur pantau SP31 yang terletak di bagian hilir setelah sekat kanal. Analisis ini untuk mengetahui keadaan elevasi Muka Air Tanah di bagian hilir setelah penyekatan kanal. Hasil analisis kenaikan MAT pada transek 3 dapat dilihat pada Gambar 9 berikut.

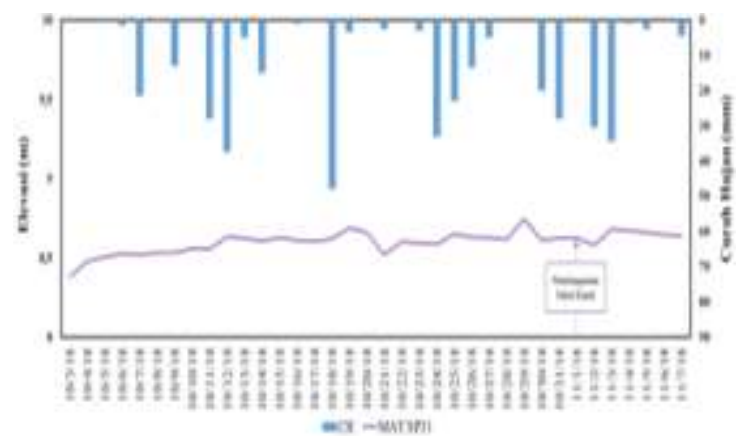

Gambar 9. Grafik Hasil Analisis Kenaikan MAT pada Transek 3

Gambar 9 di atas menunjukkan bahwa pengamatan elevasi MAT pada transek 3 yaitu pada sumur pantau SP31, kenaikan MAT tidak dipengaruhi oleh sekat kanal tetapi dipengaruhi oleh curah hujan serta juga disebabkan karena sumur pantau SP31 tersebut berada disebelah hilir setelah sekat kanal. 


\section{Analisis Fluktuasi Muka Air Tanah (MAT) Harian Pada Sumur Pantau}

Hasil analisis kenaikan MAT pada setiap sumur pantau yang berada dekat dari kanal dapat dilihat pada Gambar 10 berikut. Analisis ini dilakukan untuk memperoleh data perbedaan elevasi MAT di sebelah hulu, di tengah dan di sebelah hilir sekat kanal.

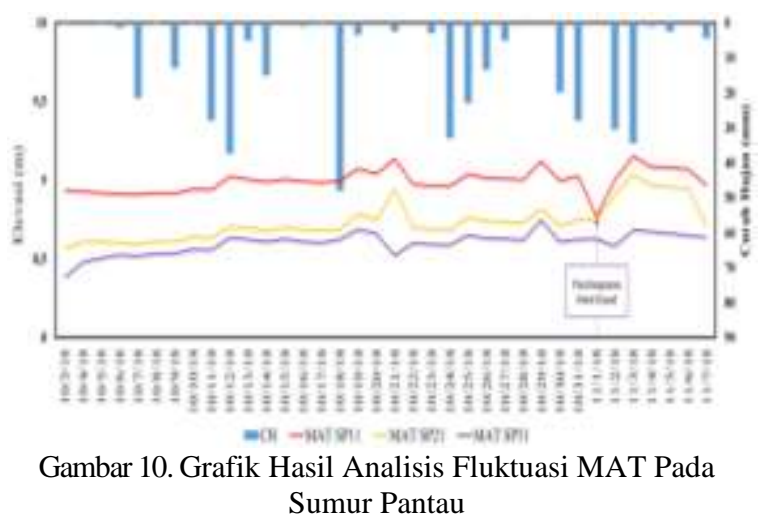

Gambar 10 di atas menunjukkan pengamatan elevasi MAT pada sumur pantau yang berada dekat dengan kanal yaitu SP11, SP21 dan SP31. Berdasarkan grafik tersebut menunjukkan bahwa sebelum adanya penyekatan kanal kenaikan MAT pada setiap sumur pantau dipengaruhi oleh curah hujan. Namun setelah adanya penyekatan kanal pada tanggal 1 November 2018, sumur pantau SP11 dan SP21 mengalami kenaikan yang signifikan hal ini dipengaruhi karena adanya penyekatan pada kanal dan sumur pantau yang dekat dengan kanal, selain itu kenaikan MAT juga dipengaruhi oleh curah hujan. Sedangkan pada sumur pantau SP31 kenaikan MAT tidak dipengaruhi oleh sekat kanal hal ini disebabkan karena letak sumur pantau yang berada disebelah hilir setelah sekat kanal tetapi kenaikan MAT pada sumur pantau SP31 lebih dipengaruhi oleh curah hujan.

Akibat besarmya curah hujan pada waktu penelitian ini sehingga hasil yang didapat kurang memuaskan yaitu pengaruh sekat kanal terhadap fluktuasi Muka Air Tanah (MAT) sebagai upaya pembasahan lahan gambut. Hal ini dikarenakan kenaikan MAT juga dipengaruhi oleh curah hujan yang besar, sehingga sulit mendapatkan data kenaikan MAT akibat penyekatan kanal.

Pada penelitian selanjutnya diharapkan dilakukan pada musim kemarau atau pada musim yang intensitas curah hujannya kecil, karena pada saat musim kemarau elevasi muka air tanah tidak dipengaruhi oleh curah hujan sehingga didapatkan data yang lebih akurat mengenai pengaruh sekat kanal terhadap fluktuasi Muka Air Tanah (MAT) sebagai upaya pembasahan lahan gambut. Selain itu, diharapkan juga pada penelitian selanjutnya untuk menganalisis lebih banyak lagi data elevasi MAT setelah penyekatan kanal agar diperoleh hasil yang lebih akurat mengenai efektifitas sekat kanal terhadap fluktuasi MAT.

\section{KESIMPULAN}

Hasil dari perhitungan dan analisis yang telah dilakukan dapat diambil kesimpulan sebagai berikut.

Berdasarkan hasil analisis dari penelitian yang dilakukan di Desa Lukun, Kabupaten Kepulauan Meranti maka dapat disimpulkan sebagai berikut.

1. Sekat kanal (canal blocking) mampu memberikan dampak atau pengaruh dalam menaikkan Muka Air Tanah (MAT) sebagai upaya pembasahan lahan gambut, meskipun secara bersamaan kenaikan MAT tersebut juga dipengaruhi oleh curah hujan.

2. Radius pembasahan lahan gambut yang dihasilkan akibat penyekatan kanal mencapai kurang dari 100 meter.

\section{DAFTAR PUSTAKA}

[1] Agus, F., dan I.G. M. Subiksa. 2008. Lahan Gambut: Potensi untuk Pertanian dan Aspek Lingkungan. Balai Penelitian Tanah dan Word Agroforestry Centre (ICRAF), Bogor, Indonesia.

[2] Bonnett, S. A., Ross, S., Linstead, C. and Maltby, E. and NaturalEngland (2009) A review of techniques for monitoring the success of peatland restoration. Technical Report. Natural England, SWIMMER.

[3] Dohong, A., Cassiophea, L., Sutikno, S., Triadi, B., Wirada, F., Rengganis, P., \& Sigalingging, L. (2017). Modul pelatihan Pembangunan Infrastruktur Pembahasan Gambut Sekat Kanal Berbasis Masyarakat. Jakarta: Badan Restorasi Gambut.

[4] Rais, D., Satriadi. (2011). Hidrologi Lahan Gambut dan Peranannya dalam Kelestarian Lahan Gambut Tropis. Prosiding Simposium Nasional Ekohidrologi, Jakarta 24 Mei 2011

[5] Taharica Group. (2018). Pengertian Sensor Water Level dan Cara Kerja. Dipetik Juni 27, 2018 dari Loggerindo: http://loggerindo.com

[6] Erlina, N. (2017). Analisis Pembangunan Canal Blocking Sebagai Solusi Pencegahan Kebakaran Lahan Gambut di Desa Sungaitohor Kabupaten Kepulauan Meranti. Jom FISIP, 4(2), 1-15.

[7] Hasfarila, H., \& et.al. (2014). Perubahan Fluktuasi Permukaan Air Tanah di Daerah Aliran Ci Leungsi Hulu Jawa Barat, 4. 
[8] Hooijer, d. (2012). Biogeosciences, vol. 9, no 3. Subsidence and carbon loss in drained tropical peatlands'.

[9] Irianto, S., dan Helmi S. R. P. (2014). Karakteristik Hidrologi Kawasan Gambut Sungai Kampar dan Sekitarnya, Provinsi Riau. In Seminar Nasional Ke - 3 Fakultas Teknik Geologi Universitas Padjajaran.

[10] Hidayati, N. (2018). Analisis Dampak Pembangunan Sekat Kanal Terhadap Fluktuasi Muka Air Tanah. Jom FTEKNIK, 5(2), 2-4.

[11] Mulyono, D. (2014). Analisis Karakteristik Curah Hujan di Wilayah Kabupaten Garut Selatan. Jurnal Konstruksi, 13(1), 3

[12] Peraturan Menteri Lingkungan Hidup dan Kehutanan Republik Indonesia No. 16 Tahun 2017 tentang Pedoman Teknis Pemulihan Fungsi Ekosistem Gambut. Dapat diakses di: www.menlhk.go.id

[13] Pradiko, H., Arwin, Soewondo, P., Suryadi, Y., \& Jatikusuma, I. (2017). Model Penerapan Drainase Berwawasan Lingkungan Skala Individu di Lahan Permukiman Kawasan Bandung Utara. Jurnal Teknik Sipil ITB, 24(1), 83-90.

[14] Pusat Studi Bencana Universitas Riau. (2017). Analisis Karakteristik Dasar, Hidrologi Gambut dan Tata Kelola Studi Kasus KHG Pulau Tebing Tinggi Kabupaten Kepulauan Meranti. Jakarta: Pusat Studi Bencana, Universitas Riau.

[15] Rais, D., Satriadi. (2011). Hidrologi Lahan Gambut dan Peranannya dalam Kelestarian Lahan Gambut Tropis. Prosiding Simposium Nasional Ekohidrologi, Jakarta 24 Mei 2011

[16] Simaremare, S. (2015). Analisis Aliran Air Tanah Satu Dimensi (Kajian Laboratorium). Teknik Sipil Dan Lingkungan, 3(1), 783-794.

[17] Suryadiputra, I. N. N., Dohong, A., Waspodo, R. S. B., Muslihat, L., Lubis, I. R., Hasudungan, F., \& Wibisono, I. T. C. (2005). Panduan Penyekatan Parit dan Saluran di Lahan Gambut Bersama Masyarakat. Bogor: Wetlands International-IP xxvi+172 hlm; ilus.; 15 x 23 cm, ISBN: 979-99373-5-3, Bogor.

[18] Sutandi, M. C. (2012). Identifikasi Sumber Air Tanah. Universitas Kristen Maranatha Bandung.

[19] Taharica Group. (2018). Pengertian Sensor Water Level dan Cara Kerja. Dipetik Juni 27, 2018 dari Loggerindo: http://loggerindo.com

[20] Tito, K. C., Ampou, E. E., Nugroho, C. S., Widagti, N., Hamzah, F., \& Zaky, R. A. (2015). Pemanfaatan Data Logger Untuk Monitoring Suhu di Nusa Penida, Bali.

[21] Utami, S. N., Maas, A., Radjagukguk, B., \& Purwanto, B. H. (2009). Restorasi Gambut Dengan Tiga Jenis Surfaktan, Dan
Pengaruhnya Terhadap Efisiensi Penyimpanan Kation Dan Kapasitas Memegang Air. AGRITECT, 29(1), 36-41.

[22] Utomo, A., Hendarmawan., \& Hadian, D. S. M. (2017). Karakteristik Fluktuasi Permukaan Air Tanah Pada Akuifer Tidak Tertekan di Kelurahan Cibabat, Kecamatan Cimahi Utara, Kota Cimahi. Jurnal Lingkungan dan Bencana Geologi, 8(3), 117-126.

[23] Yuliani, F. (2017). Pelaksanaan Cannal Blocking Sebagai Upaya Restorasi Gambut di Kabupaten Meranti Provinsi Riau. Spirit Publik, 12(1), 69-84.

[24] Yulianto A. (2011). Data Logger (bagian 1). http://sonoku.com/data-logger bagian-1/ diakses pada 28 Mei 2015. 